\title{
Through the Looking Glass: Interpreting Growing Success, The Kindergarten Addendum, Ontario's Assessment, Evaluation, and Reporting Policy Document
}

\author{
Kelly-Ann MacAlpine
}

Kelly-Ann MacAlpine is a PhD student in the Curriculum Studies Program at the Faculty of Education, Western University. With particular attention to early childhood education and care, she is curious about the posthumanist perspective that shifts the conversation from universal truths to boundless possibilities in the blurring of knowing and being. Her area of interest focuses on a pedagogy of listening and the ethics of the encounter through attending to the presence of multiple perspectives. By understanding the ever-evolving and complicated entanglement of human and nonhuman relationships in the process of meaning making, she seeks to research the emerging role of pedagogical documentation as it intersects curriculum and pedagogical practice. Email: kmacalp2@ uwo.ca

Transforming the early years program to reflect changing perspectives is not an easy task, particularly in the context of assessment, evaluation, and reporting. This article explores the interplay of alternative perspectives in a critical look at Ontario, Canada's newly released policy document Growing Success, The Kindergarten Addendum: Assessment, Evaluation, and Reporting in Ontario Schools (Ontario Ministry of Education, 2016b). As the kindergarten program calls for transformation in pedagogical approaches, its assessment policy seems to stutter as it attempts to keep pace. Through unpacking the assessment addendum, this article introduces potential alternative interpretations of the purpose of assessment from constructivist and social constructivist perspectives, illustrating key challenges in the transformation process. This muddled cojoining of perspectives highlights a lack of clarity in purpose of the kindergarten program which has the potential to negatively affect both child and educator, while leaving parents and community confused and befuddled.

Keywords: early childhood education; kindergarten; assessment; policy; constructivist perspective; social constructivist perspective

constructivist, and posthumanist perspectives. It asks how the content of the Growing Success policy document offers the potential for multiple interpretations of how it utilizes the concept and practice of assessment within its text:

1. Constructivist perspective: How is assessment utilized as proof and "product of learning"?

2. Social constructivist perspective: How is assessment utilized for "meaning making" in the "process of learning"?

3. Posthumanist perspective: How is assessment utilized within the "process of being and knowing"?

I contend that the assessment policy document is dominated by the constructivist perspective, offering limited representation from 
the social constructivist perspective, and retaining no reference to a posthumanist perspective. It leaves no clear direction toward utilizing any of the theoretical underpinnings. There is a potential tension as educators reconcile their practice in order to adhere to the provincially mandated policies and procedures while acknowledging the coconstructive nature of learning and children's rights as confident, capable, and competent learners (Pence \& Pacini-Ketchabaw, 2008, 2010). Further, this muddled cojoining of perspectives contributes to a lack of clarity in purpose, and therefore has the potential to negatively affect both child and educator, while leaving parents and community confused and befuddled.

\section{Background}

Lewis Carroll's novel Through the Looking Glass offers the reader a glimpse into the "playfulness" of multiple meanings of words. While the characters Alice and Humpty Dumpty engage in a back and forth banter, a friendly dispute arises over who has the "right" meaning of a word.

"The question is," said Alice, "whether you CAN make words mean so many different things." (Carroll, 1897/2011, p. 142)

Much like the words uttered by Alice, I too wonder whether you CAN make words have multiple meanings, and what impact multiple meanings have when occupying the same space.

Considering the exploratory nature of my research, I have chosen interpretive hermeneutics to frame my analysis. As "the interpretive act of understanding" (Kinsella, 2006, p. 1), interpretive hermeneutics is used to discover meaning and understanding of text (Kinsella, 2006; Mantzavinos, 2016; Rennie, 2012; Skodol Wilson \& Hutchinson, 1991). Particularly important is the concept of continuous shifts in understanding of text and its effect on future understandings in an ever-evolving "hermeneutic spiral" (Bradley, 1993, p. 434). I do not seek to disclose, nor is it possible to fully understand, the author's intended purpose of a text, but I will reconstruct the relationships of meaning to fit within my alternative objectives. I am looking to understand assessment within differing perspectives that may not necessarily reflect the author's intentions. This appropriation of meaning involves "inventing interpretations as reconstructions of nexuses of meaning with respect to different aims" (Mantzarinos, 2016, "Aims of Text Interpretation," para. 7). In other words, I will be deconstructing parts of the Growing Success policy document to illustrate potential meanings within particular phrases that represent different theoretical perspectives and their ensuing purpose of assessment.

\section{Multiple Meanings of Assessment}

Multiple meanings pose a challenge when developing an understanding of a concept. Continuing with my example from Through the Looking Glass, the nonsensical banter between the two characters, Humpty Dumpty and Alice, gives readers a humorous look into the dilemma whereby multiple meanings compete to occupy the same space. Alice argues that " 'glory' doesn't mean 'a nice knock-down argument"' (Carroll, 1897/2011, p. 141), but Humpty Dumpty disagrees, responding emphatically that "when I use a word ... it means just what I choose it to mean ... [for] you see, it's like a portmanteau—-there are two meanings packed up into one word," leaving Alice all the more "puzzled" (pp. 142-143). Although fictitious, Lewis Carroll's fantasy novel seems to capture how perspective impacts the interpretive nature of meaning making. Multiple interpretations based on perspective affect conceptual and contextual meanings (Anward, 1994; Stables \& Semetsky, 2015). It is the utilization of alternative meanings that I am most interested in, particularly how a word or phrase, within the same context, might encompass different meanings. For example, the place and purpose of assessment is understood differently from a constructivist, social constructivist, and posthumanist perspective, as discussed below.

\section{Assessment from a constructivist perspective}

Based on the positivist theory of universal truth and the stable, predictable, and linear order in learning and meaning making, assessment has come to reflect evidence of learning (Cannella, 2008; Curry \& Cannella, 2013; Dahlberg, Moss, \& Pence, 2013; Lenz Taguchi, 2010). From a constructivist perspective, assessment is often times associated with meeting predetermined objectives, with teacher practices "focus[ed] on judging individual achievement in relation to pre-set goals and outcomes" (Lenz Taguchi, 2010, p. 9). The purpose of assessment places proof of, or product of, learning at the forefront. The constructivist perspective identifies "education and learning as being about children attaining normative development and knowledge, and achieving a set of predetermined outcomes ... [utilizing assessment to determine] whether children achieve the required and defined standards" (Dahlberg \& Moss, 2005, p. 95). 
As identified within a constructivist perspective, assessment is often associated with developmental checklists and with determining whether a child meets or fails to meet predetermined levels of growth as "proof of learning."

\section{Assessment from a social constructivist perspective}

With the reconceptualization of early childhood education, there has been a "rethinking" that "emphasizes more socially just and diverse ways of knowing, being, and doing" (Curry \& Cannella, 2013, p. ix), leaving open a route for shifting pedagogical practices. From a social constructivist perspective, assessment focuses on the process of learning. As Dahlberg, Moss, and Pence (2013) note, although both the constructivist and social constructivist perspectives "see an active and problem-solving child" (p. 59), assessment shifts from the constructivist perspective of the "child existing within a context of standardized, stable and objective concepts" to the social constructivists' emphasis on assessing the process of learning (p. 59). By acknowledging the coconstructive nature of learning and children's rights as confident, capable, and competent learners, the meaning and purpose of assessment, as in the context of the kindergarten program, changes (Cannella, 2008; Curry \& Cannella, 2013; Lenz Taguchi, 2010). Rather than "proof of learning," the focus shifts to the process of learning and the use of documentation, or, more aptly, pedagogical documentation, to reflect on and inform an educator's pedagogical practice (Pence \& Pacini-Ketchabaw, 2008; Wien, 2013; Wien, Guyevsky, \& Berdoussis, 2011).

\section{Assessment from a posthumanist perspective}

As the posthumanist perspective blurs knowing and being, there is a call for a complete shift in thinking, from "judging individual achievement in relation to pre-set goals and outcomes" to "engage[ing] in collaborative knowledge-production with children that challenge their and our own possibilities and potentialities beyond what we already think we know" (Lenz Taguchi, 2010, p. 9). Although both the social constructivist and posthumanist perspectives emphasize the process of learning and the notion of making learning visible, highlighting the "complexities and diversities of learning and knowing" (Lenz Taguchi, 2010, p. 8), the posthumanist perspective takes the complexity of learning farther. It emphasizes the entangling of knowing and being, whereby "discourse is just as much produced by way of the agentic qualities of the material world around us as it intra-acts with us, as it is produced by the limitations of our perceptive, intra-acting and conceptualising mind" (Lenz Taguchi, 2010, p. 49). The documentation of the assessment becomes a provocative influence as it becomes active in the process of knowing and being.

Educators are seemingly challenged as they try to navigate the theory/practice interdependence as necessitated within the study of education and learning (Cannella, 2008; Lenz Taguchi, 2010; Yelland, 2012). Within the theoretical frameworks of the constructivist, social constructivist, and posthumanist perspectives, there are unique interpretations of the meaning and purpose of assessment. It is important to note that each of these perspectives is philosophically and theoretically different, and aligning to one would affect one's practice, including the purpose of assessment and utilization of pedagogical documentation (Cannella, 2008; Dahlberg et al., 2013).

Interpreting the Growing Success policy document will depend on the perspective with which you align and the lens you use. But what effect would there be if these different perspectives were reflected in the same policy document?

\section{Current Research}

As I began my research on the utilization of pedagogical documentation within the context of Ontario's new kindergarten program, I noticed a trend emerging in the literature, whereby educators were struggling to fit pedagogical documentation and assessment together in their practice (Basford \& Bath, 2014; Blandford \& Knowles, 2012; MacDonald, 2007; Pyle \& Bigelow, 2015; Pyle \& DeLuca, 2013). Basford and Bath (2014) note a similar quandary as they discuss the notion of "competing assessment paradigms" (p. 123), problematizing "whether it is possible to apply a conforming, subverting binary to practice that can nevertheless still be transformative in the hands of practitioners" (p. 128). In other words, transformation may be impeded when competing perspectives occupy the same space.

On a provincial, national, and international stage, current research looks at how the purpose of assessment affects pedagogical documentation (Basford \& Bath, 2014; Buldu, 2010; Knauf, 2015; MacDonald, 2007; Pyle \& DeLuca, 2013; Rintakorpi, 2016). An example, found in a recent Canadian study, concluded that pedagogical documentation is defined within the context of assessment, and that regardless of the teacher approach or curricular stance, documentation is "construed in relation to an overall framework of educational accountability" (Pyle \& Deluca, 2013, p. 232). Although my research has been focusing on the utilization of pedagogical documentation as bounded within constructivist, social constructivist, and posthumanist perspectives and positioned within the same guiding kindergarten curriculum and policy documents, it is worth noting the strong connection between pedagogical documentation 
and assessment. Within the context of Ontario's call for "transformational changes in pedagogical approaches" (Ontario Ministry of Education, 2016b, p. 4), understanding the purpose of assessment becomes an important component affecting these changes.

\section{Ontario Context}

The current kindergarten program (Ontario Ministry of Education, 2016b) and its corresponding policy document Growing Success (Ontario Ministry of Education, 2016a) offer a unique landscape to explore how alternative perspectives compete to occupy the same space. With the kindergarten program, educators are guided by three leading documents: How Does Learning Happen? Ontario's Pedagogy for the Early Years (Ontario Ministry of Education, 2014); The Kindergarten Program; and Growing Success. With the pedagogy policy document supporting change in pedagogical practice and the curriculum document calling for transformation, one might expect a complete shift from past traditional developmental pedagogies toward the Reggio-inspired pedagogies of listening. In fact, the curriculum document (Ontario Ministry of Education, 2016b) states that the intention is to move "from a traditional pedagogy to one centred on the child and informed by evidence from research and practice about how young children learn" (p. 4) and that "the insights of educators in the field, along with knowledge gained from national and international research on early learning, have informed the development of [this] document" (p. 4).

The Growing Success policy document lays out the provincially mandated policies and procedures from which educators are to assess, evaluate, and report on students' achievement in meeting set expectations. The policy document defines assessment as the

process of gathering and interpreting information that accurately reflects the child's demonstration of learning in relation to the knowledge and skills outlined in the overall expectations of The Kindergarten Program (2016). The primary purpose of assessment is to improve learning and to help children become self-regulating, autonomous learners, with children's growth and learning in relation to the overall expectations within each frame ... evaluated on the basis of specific expectations. (pp. 6, 10)

Reporting on student progress is to be conducted on an ongoing basis, as well as recorded within three formal reports to be distributed to parents and retained as part of a child's permanent Ontario Student Record.

Broad sweeping statements found within both the curriculum and assessment documents leave open the opportunity for the readers to interpret what is meant by statements such as "centred on the child" or "evidence from research." For example, the concept of child centeredness is "very abstract and rather problematic" (Dahlberg, Moss, \& Pence, 2013, p. 46), therefore leaving it open to a multitude of interpretations. Problems begin to surface when analyzing the context of the assessment policy document to reflect "transformational changes in the pedagogical approaches (Ontario Ministry of Education, 2016b, p. 4). Within the deconstruction process, interpreting key phrases offers conflicting messages, and I would argue that "centred on the child" could fit within the boundaries of a constructivist and social constructivist perspective; the difference lies in what each defines as the meaning of the words. The structure of the reporting system is ambiguous, creating mixed messages in the purpose of assessment.

By defining assessment in the Growing Success policy document as the "process of gathering and interpreting information that accurately reflects the child's demonstration of learning in relation to the knowledge and skills outlined in the overall expectations" ( $p$. 6), it is possible to interpret its meaning within a constructivist perspective. I would argue that, by providing this particular phrasing to define assessment, the document indicates the necessity for educators to gather evidence and for students to demonstrate levels of competency in prescribed expectations in order to provide proof of learning. The primary purpose of assessment is to improve learning and to help children become self-regulating, autonomous learners, with children's "growth and learning in relation to the overall expectations within each frame ... evaluated on the basis of specific expectations" (p. 10). From my point of view, there is a clash between reporting on "meeting the success criteria [and] documenting successes of learning" (p. 7) with the provision that educators "develop and maintain a collaborative, complementary, and reciprocal relationship with children and their families" (p. 5).

The question becomes whether it is possible to make room for two competing perspectives. Is it possible to collaborate in the coconstruction of learning when set objectives have already been identified as specifics to be taught? For example, within the "notice and naming" section, the document gives a somewhat ambiguous description by stating that "children come to understand what growth in their learning "looks like'" (p. 7), leaving the text open to interpretation. From a constructivist perspective, naming and labelling concepts such as patterning affords the teacher the opportunity to provide the description of the skill the child is to demonstrate. Alternatively, from a social constructivist perspective, the statement affords the child an opportunity to actively 
contribute to the process of learning.

Although comprised of strategically placed rhetoric that indicates shifting perspectives, there are points within the policy document that have the potential for mixed meanings. As stated previously, within the assessment "for" and "as" section of the policy document, Growing Success places assessment as "the process of gathering and interpreting information that accurately reflects the child's demonstration of learning in relation to the knowledge and skills outlined in the overall expectations of The Kindergarten Program" (p. 6) and states that "the primary purpose of assessment is to improve learning and to help children become self-regulating, autonomous learners" (p. 10). The debate becomes whether the statement indicates the social constructivist perspective, which views the child as a coparticipant actively involved in the learning process, or the constructivist perspective, which views the child as a passive participant who is directed toward learning goals that have been predetermined. From my perspective, when interpreting this phrasing, assessment is based on "evidence" or "proof of learning." Using terminology such as "demonstration of learning" and "overall expectations" indicates a traditional constructivist perspective whereby goals are predetermined (Basford \& Bath, 2014). With the presence of mixed meanings, the policy document may be subject to alternative interpretations.

The fundamental principles make use of assessment for learning, as learning, and of learning (Ontario Ministry of Education, 2016a). Interestingly enough, the document defines assessment, in part, as "the process of gathering and interpreting information that accurately reflects the child's demonstration of learning" (Ontario Ministry of Education, 2016a, p. 6). This quote, when taken out of context, could be indicative of the purpose of assessment being learner driven. But again, with deeper analysis, it becomes muddled as it gives reference to "knowledge and skills outlined in the overall expectation of The Kindergarten Program" (Ontario Ministry of Education, 2016a, p. 6). I find it difficult to reconcile the use of the term "learner driven" when objectives are set prior to any learning event.

Within Growing Success, it notes that assessment is used for eliciting information about children's learning, providing descriptive feedback, developing children's self-assessment and peer-assessment skills, developing individual goal-setting skills, and developing self-regulation skills. I would agree that, as in the example of providing descriptive feedback, assessment does "help children to progress in their learning" (p. 8). In this context, assessment fits within the social constructivist approach. Therefore, it does meet its own objectives of transforming its pedagogical approach because it acknowledges the active process of learning. Since the descriptive feedback is clearly directed toward how the student must meet the overall expectations of the Ministry's preassigned outcomes and goals, it seems to straddle the two perspectives.

Indicative of how these mixed meanings impact practice, a recent study indicated that, although educators acknowledged an understanding and need for pedagogical documentation, difficulty arose when they tried to reconcile its use over traditional observations to record "proof of learning" that the teachers felt was needed for reporting on meeting government-mandated objectives (Pyle \& Deluca, 2013). This particular study took place in Ontario and was subject to the previous government policy on assessment; however, I would suggest that both policies (Ontario Ministry of Education, 2010, 2016b) have been governed by similar mandates. Further, within the discussion section, the authors of the study noted great divides in assessment approaches, stating that although "all teachers were using the same curricular documents, meeting the same academic standards, and working within the same school district ... assessment programs within the local kindergarten classrooms differed widely" (Pyle \& Deluca, 2013, p. 379). This observation suggests that multiple varying meanings were used within the interpretation of the policy document and ultimately in educators' pedagogical approach.

When considering pedagogical approach, the policy document set out seven fundamental principles to ensure validity and reliability in reporting (Ontario Ministry of Education, 2016a). On the surface, these principles seem to describe assessment as fair, supportive, individualized, and inclusive, but on closer inspection, contradiction can be seen between supporting the "interests, learning styles and preferences, needs, and experiences" of the student and "carefully planned [assessment] to relate to the curriculum expectations and learning goals" (Ontario Ministry of Education, 2016a, p. 4). Although these principles are in place to give clarity and purpose to assessment, they do not reflect our emerging understanding of the child as an active contributor and constructor of learning (Cannella, 2008; Prochner \& Pacini-Ketchabaw, 2013), because they fail to identify the learner's needs, instead focusing on prescribed future needs as set out by others. This clearly indicates a constructivist perspective. While focusing on the learner becoming a competent future member of society by assessing success or failure to meet objectives, it fails to recognize the child as a competent being and a rightful citizen today (Dahlberg \& Moss, 2005; Hall \& Rudkin, 2011). As noted in How Does Learning Happen?, "when we recognize children as capable and curious, we are more likely to deliver programs and services that value and build on their strengths and abilities" (Ontario Ministry of Education, 2014, p. 6). But, with the continual referencing to predetermined learning goals and "children's growth and learning in relation to the overall expectations within each frame [which] are evaluated on the basis of specific 
expectation associated with the overall expectations, [and which] must be accounted for in instruction and assessment" (p. 10, italics added), the policy document stifles the educator's and student's voice and agency as active coconstructors.

\section{Evaluation}

The policy document divides its evaluation domains to reflect the kindergarten program's four frames of learning (belonging and contributing; self-regulation and well-being; demonstrating literacy and mathematics behaviours; and problem solving and innovating). Children are evaluated on objectives within these frames to determine whether they are "ready to learn." What is interesting in this case is what could be the implied meaning of ready to learn and its counterpart, "what learning looks like" (p. 7). Is it a skill that needs to be taught in an orderly way, or is it a disposition that is already present? In describing teacher strategies for extending learning in its "noticing and naming" piece, the goal seems to be to identify a particular set skill, such as patterning, in order to make learning visible to the child and provide "the link to more formal approaches in the use of learning goals and success criteria in the later grades" (p. 7). Does patterning become a necessary skill required to meet the demonstration of mathematics behaviour? Does this skill secure a child's success in a traditional top-down model of education?

Evaluation, in its use in education, has been defined as a process that "involves the judging and interpreting of evidence of learning to determine children's growth and learning in relation to the overall expectations outlined in The Kindergarten Program" (Ontario Ministry of Education, 2016a, p. 10). In a sense, evaluation reports on whether a child meets or, implicitly, fails to meet expectations. This understanding of evaluation is very much removed from its Latin origin, meaning to strengthen or empower, with it now being (re)defined as being "largely about the measurement of things [so that therefore] in the process [it] can easily slip into becoming an end rather than a means" (Smith, 2001/2006, para. 3). Although it states early on in the policy document that the child is "actively engaged in the assessment process" (p. 3) it does not provide the context for this statement. Further, in my opinion it focuses not on the child's active participation in the assessment process, but rather identifies what is necessary for children to display within the parameters of assessment criteria the educator is required to observe. For example, within the noticing and naming the learning section, the policy document indicates that "children come to understand what growth in their learning 'looks like' ... [and educators] make the children's thinking and learning "visible to them"' (p. 7). The policy thus places evaluation within the constructivist perspective.

\section{Reporting}

With evaluation comes reporting. Starting in September 2016, the kindergarten program will be mandated to document and report. This mandate offers a strong indication that the kindergarten program becomes part of the formal top-down reporting system seen in grades 1 through 12. I wonder if this is a contradiction in policy intentions? The policy document describes itself as having "a profound, positive impact not only on children's learning but also on their motivation to learn and their confidence in their ability to do so" (p. 4), and highlights that "[documenting] the evidence of learning is the most important aspect of assessment in Kindergarten and is, indeed, an integral part of all assessment approaches" (p. 8). Thus one might argue that it does indeed transform its approach to a social constructivist perspective. However, although introduced as the next step toward ensuring a child's growing success, I am left with concerns. This policy document seems to provoke many different interpretations of what the roles of the educator and learner are, leaving me with an impression of what might be a shaky foundation for lifelong learning for these young children, especially as is illustrated with the continuous reiteration of "meeting expectations" and providing "evidence of learning." I would argue that having set expectations in place leaves little room for active participation by the learner as a cocontributor and coconstructor of the ongoing learning process.

\section{Concluding Remarks}

Is it possible to meet provincially mandated policies and procedures while acknowledging and incorporating notions of the coconstructive nature of learning in pedagogical practices? The question becomes whether the Growing Success policy document is viable when related back to the original intention of Ontario's new kindergarten program. In short, I would suggest that a lack of cohesion fails to support either the educator or the child. This critique offers a different interpretation to what has been described by the Ontario Ministry of Education (2016a) as providing a "profound, positive impact not only on children's learning but also on their motivation to learn and their confidence in their ability to do so" (p. 4). From my perspective, this policy document does not reflect the original call for transformational changes, as highlighted in the kindergarten program, but rather reflects a struggle between two dominant perspectives. If I were to assess, evaluate, and report on the Growing Success policy document, I would offer up a "fails to 
meet" in its attempt to create a foundational policy that fully meets the expectations it sets out to accomplish.

On one last note, this article was scribed for the sole purpose of problematizing existing policies. Although its critique is harsh at times, the intent was not to strike down an existing policy document but rather to provoke continued dialogue and action as we navigate this journey of transformation.

\section{References}

Anward, J. (1994). Semiotics in educational research. International Encyclopedia of Educational Research, 9, 5411-5417. Retrieved from: https://liu.se/ikk/medarbetare/jan-anward/filarkiv-publikationer/1.209695/ja-1994a-semiotics.pdf

Basford, J., \& Bath, C. (2014). Playing the assessment game: An English early childhood education perspective. Early Years, 34(2), 119-132. doi: 10.1080/09575146.2014.903386

Blandford, S., \& Knowles, C. (2012). Assessment for learning: A model for the development of a child's self-competence in the early years of education. International Journal of Primary, Elementary, and Early Years Education, 40(5), 487-499. doi: $10.1080 / 03004279.2010 .548818$

Bradley, J. (1993). Methodological issues and practices in qualitative research. Library Quarterly, 63(4), 431-449.

Buldu, M. (2010). Making learning visible in kindergarten classrooms: Pedagogical documentation as a formative assessment technique. Teaching and Teacher Education, 26, 1439-1449. doi: 10.1016/j.tate.2010.05.003

Cannella, G. (2008). Deconstructing early childhood education: Social justice and revolution. Rethinking Childhood, 2. New York, NY: Peter Lang.

Carroll, L. (2011, March 3). Through the looking-glass and what Alice found there. Bookbyte Digital Edition. (Original work published 1897)

Curry, D., \& Cannella, G. (2013). Reconceptualist her/histories in early childhood studies: Challenges, power regulations, and critical activism. In V. Pacini-Ketchabaw \& L. Prochner (Eds.), Re-situating Canadian early childhood education (pp. ix-xxvi). New York, NY: Peter Lang.

Dahlberg, G., \& Moss, P. (2005). Ethics and politics in early childhood education. New York, NY: Routledge Taylor \& Francis Group.

Dahlberg, G., Moss, P., \& Pence, A. (2013). Beyond quality in early childhood education and care: Languages of evaluation ( $3^{\text {rd }}$ ed.). New York, NY: Routledge Taylor \& Francis Group.

Hall, E., \& Rudkin, J. (2011). Seen and heard: Children's rights in early childhood education. London, ON: Althouse Press.

Kinsella, E. (2006). Hermeneutics and critical hermeneutics: Exploring possibilities within the art of interpretation. Forum: Qualitative Social Research, 77(3), Art. 19. Retrieved from: http://www.qualitative-research.net/index.php/fqs/article/ view/145/319

Knauf, H. (2015). Styles of documentation in German early childhood education. Early Years, 35(3), 232-248. doi: $10.1080 / 09575146.2015 .1011066$

Lenz Taguchi, H. (2010). Going beyond the theory/practice divide in early childhood education: Introducing an intra-active pedagogy. New York, NY: Routledge Taylor \& Francis Group.

MacDonald, M. (2007). Toward formative assessment: The use of pedagogical documentation in early elementary classrooms. Early Childhood Research Quarterly, 22, 232-242. doi: 10.1016/j.ecresq.2006.12.001 
Mantzavinos, C. (2016). Hermeneutics. Stanford Encyclopedia of Philosophy. Retrieved from: https://plato.stanford.edu/archives/ win2016/entries/hermeneutics

Ontario Ministry of Education. (2014). How does learning happen? Ontario's pedagogy for early years. Toronto, ON: Queen's Printer for Ontario. Retrieved from: http://www.edu.gov.on.ca/childcare/HowLearningHappens.pdf

Ontario Ministry of Education. (2016a). Growing success: The kindergarten addendum: Assessment, evaluation, and reporting in Ontario schools. Toronto, ON: Queen's Printer for Ontario. Retrieved from: http://www.edu.gov.on.ca/eng/policyfunding/ growingSuccessAddendum.pdf

Ontario Ministry of Education. (2016b). The kindergarten program. Toronto, ON: Queen's Printer for Ontario. Retrieved from: https:// files.ontario.ca/books/edu_the_kindergarten_program_english_aoda_web_oct7.pdf

Pence, A., \& Pacini-Ketchabaw, V. (2008). Discourses on quality care: The Investigating 'Quality' project and the Canadian experience. Contemporary Issues in Early Childhood, 9(3), 241-255. doi: 10.2304/ciec.2008.9.3.241

Pence, A., \& Pacini-Ketchabaw, V. (2010). Investigating Quality project: opening possibilities in early childhood care and educations policies and practices in Canada. In N. Yelland (Ed), Contemporary perspectives on early childhood education (pp. 121138). New York: McGraw-Hill Education.

Prochner, L., \& Pacini-Ketchabaw, V. (2013). Re-situating early childhood education: Introduction. In V. Pacini-Ketchabaw \& L. Prochner (Eds.), Re-situating Canadian early childhood education (pp.1-14). New York, NY: Peter Lang.

Pyle, A., \& Bigelow, A. (2015). Play in kindergarten: An interview and observational study in three Canadian classrooms. Early Childhood Education Journal, 43, 385-393. doi: 10.1007/s10643-014-0666-1

Pyle, A., \& DeLuca, C. (2013). Assessment in the kindergarten classroom: An empirical study of teachers' assessment approaches. Early Childhood Education Journal, 41, 373-380. doi: 10.1007/s10643-012-0573-2

Rennie, D. (2012). Qualitative research as methodical hermeneutics. American Psychological Association, 17(3), 385-398. doi: $10.1037 / \mathrm{a} 0029250$

Rintakorpi, K. (2016). Documenting with early childhood education teachers: Pedagogical documentation as a tool for developing early childhood pedagogy and practices. Early Years, 36(4), 399-412. doi: 10.1080/09575.2016.1145628

Skodal Wilson, H., \& Hutchinson, S. (1991), Pearls, pith, and provocation: Triangulation of qualitative methods: Heideggerian hermeneutics and grounded theory. Qualitative Health Research, 1(2), 263-276. doi: 10.1177/104973239100100206

Smith, M. K. (2001, 2006). Evaluation. The Encyclopedia of Informal Education. Retrieved from: http://infed.org/mobi/evaluationtheory-and-practice/

Stables, A., \& Semetsky, I. (2015). Edusemiotics: Semiotic philosophy as educational foundation. New York, NY: Routledge Taylor Francis Group.

Wien, C. (2013). Making learning visible through pedagogical documentation. Retrieved from: http://www.edu.gov.on.ca/childcare/ Wien.pdf

Wien, C., Guyevsky, V., \& Berdoussis, N. (2011). Learning to document in Reggio-inspired education. ECRP Early Childhood Research \& Practice, 13(2). Retrieved from: http://ecrp.uiuc.edu/v13n2/wien.html

Yelland, N. (2010). Contemporary perspectives on early childhood education. New York, NY: McGraw-Hill. 